\title{
Multiple GTP-Binding Proteins from Cholinergic Synaptic Vesicles
}

\author{
Johnny K. Ngsee, Kenneth Miller, Beverly Wendland, and Richard H. Scheller \\ Department of Biological Sciences, Stanford University, Stanford, California 94305
}

\begin{abstract}
Cholinergic synaptic vesicles purified from the electric organ of the marine ray, Discopyge ommata, contain 2 different size classes of GTP-binding proteins: one or more with an apparent molecular weight (MW) between 37 and $41 \mathrm{kDa}$, and 3 major and at least 2 minor proteins with MW between 20 and 29 kDa. These GTP-binding proteins were detectable using the $\alpha^{32 P}$-GTP overlay technique and covalent modification with bacterial toxins. The higher MW GTP-binding proteins are ADP-ribosylated by pertussis toxin and 2 of the lower MW GTP-binding proteins are sensitive to botulinum toxin.
\end{abstract}

The $\mathrm{G}$ proteins, consisting of heterotrimeric $\alpha, \beta$, and $\gamma$ subunits, are involved in receptor-mediated signal transduction (for reviews, see Stryer, 1986; Gilman, 1987; Milligan, 1988). The $\alpha$ subunit, with an apparent molecular weight (MW) between 39 and $52 \mathrm{kDa}$, is inactive in the GDP-bound form and remains associated with the $\beta \gamma$ subunits. Upon activation, GTP is exchanged for the bound GDP and the $\alpha$ subunit dissociates from the $\beta \gamma$ subunits to interact with the effector system. Hydrolysis of the bound GTP leads to reassociation with the $\beta \gamma$ subunits and regeneration of the inactive complex. The complex is usually localized to the inner surface of the plasma membrane, although recently these protcins have been detected on chromaffin granule membranes (Tanaka et al., 1987; Toutant et al., 1987; Brocklehurst and Pollard, 1988). Another family of GTPbinding proteins, with an apparent MW between 20 and $29 \mathrm{kDa}$, is found in many mammalian tissues, including brain (Kikuchi et al., 1988a, b), adrenal gland (Morii et al., 1988), adrenal chromaffin cells (Burgoyne and Morgan, 1989; Doucet et al., 1989), platelets (Banga et al., 1988; Bhullar and Haslam, 1988), and neutrophils (Bokoch et al., 1988). These GTP-binding proteins include the ras family (for review, see Barbacid, 1987), rho (Madaule and Axel, 1985), rab (Touchet et al., 1987), and ral (Chardin and Tavitian, 1986). Four other GTP-binding proteins, denoted smg p21 (Matsui et al., 1988), and 3 related smg p25A, p25B, and p25C (Kawata et al., 1988), have been cloned from a bovine brain cDNA library using oligonucleotide probes deduced from amino acid sequences. By analogy to the $\alpha$ subunit and the localization of ras protein to the inner surface of the plasma membrane, they have also been implicated to play a role in signal transduction. More recently, ras in conjunction with GTPase-activating protein (GAP) has been shown to be modulated by the phosphatidylinositol secondary messenger pathway (Tsai et al., 1989).

Received May 18, 1989; revised July 19, 1989; accepted July 21, 1989.

Correspondence should be addressed to Dr. Richard H. Scheller at the above address.

Copyright (C) 1990 Society for Neuroscience $0270-6474 / 90 / 010317-06 \$ 02.00 / 0$
As an alternative to their signal-transduction role, the lowerMW GTP-binding proteins have been proposed to be involved in regulating the vectorial transport of intracellular vesicles (Bourne, 1988). This is supported by the identification of GTPbinding proteins such as Yptl in the Golgi complex (Schmitt et al., 1986; Segev et al., 1988), Sec4 in secretory vesicles and plasma membrane (Salminen and Novick, 1987; Goud et al., 1988), and disruption of the constitutive secretory process in yeast caused by mutation in either of these 2 GTP-binding proteins. Furthermore, the identification of a $\mathrm{G}_{\mathrm{i}}$-like protein in the rough endoplasmic reticulum (Audigier et al., 1988) and the ability of the nonhydrolyzable GTP analog GTP $\gamma$ S to block the fusion of vesicles derived from the Golgi complex (Melancon et al., 1987) imply that GTP-binding proteins may be involved in trafficking of intracellular vesicles in mammalian systems. It is likely that GTP-binding proteins are also involved in regulating synaptic vesicle trafficking and synaptic transmission in neurons. For example, botulinum toxin is known to inhibit the quantal release of neurotransmitters (Simpson, 1986; Habermann and Dreyer, 1986; Dunant et al., 1988; Poulain et al., 1988) and to catalyze the ADP-ribosylation of certain low-MW GTP-binding proteins (Ohasi and Narumiya, 1987; Narumiya et al., 1988; Matsuoko et al., 1989).

As a prerequisite to mediating critical aspects of signal transduction and synaptic transmission or regulating the vectorial transport of secretory vesicles, it is essential that the GTP-binding proteins involved be localized near the synapse or associated with synaptic vesicles. This report demonstrates that 2 sets of GTP-binding proteins, one with apparent MW between 37 and $41 \mathrm{kDa}$ and a second between 20 and $29 \mathrm{kDa}$, are localized in or on the synaptic vesicles of Discopyge ommata. Moreover, they served as substrates for ADP-ribosylation by pertussis and botulinum toxins.

\section{Materials and Methods}

Purification of cholinergic synaptic vesicles. Synaptic vesicles were prepared from the electric organs of the marine ray, D. ommata, as described previously (Carlson et al., 1978; Wagner et al., 1978). The frozen tissue was ground to a fine powder under liquid nitrogen and resuspended in $10 \mathrm{~mm}$ HEPES-NaOH, pH $7.0,0.4 \mathrm{~m} \mathrm{NaCl}, 10 \mathrm{~mm}$ EGTA, $0.044 \mathrm{mg} / \mathrm{ml}$ aprotinin, and $0.4 \mathrm{mM}$ PMSF. The suspension was then homogenized for $2 \mathrm{~min}$ in a Waring blender. The homogenate was subjected to differential centrifugation at $30,000 \times \mathrm{g}$ for $30 \mathrm{~min}$ to remove cell debris and large membranous organelles. The supernatant fraction was then centrifuged at $100,000 \times g$ for $4 \mathrm{hr}$. The membrane pellet was resuspended in $10 \mathrm{~mm}$ HEPES-NaOH, $\mathrm{pH} 7.0,0.8 \mathrm{~m}$ sucrose, $10 \mathrm{~mm}$ EGTA using a Teflon-glass Dounce homogenizer and underlaid on a discontinuous sucrose gradient containing $0.65,0.45$, and $0.2 \mathrm{M}$ sucrose steps. The gradient was subjected to centrifugation at 100,000 $\times g$ for $16 \mathrm{hr}$. Fractions $(2 \mathrm{ml})$ were collected from the top and analyzed for ATP content and $\alpha^{32}$ P-GTP-binding activity.

The ATP-containing fractions were pooled and further purified through a controlled pore glass (CPG) column. Fractions $(5 \mathrm{ml})$ were monitored 


\section{Electric Organ Homogenate}

Figure 1. Purification of synaptic vesicles from the electric organ of $D$. ommata. The homogenate was subjected to differential centrifugation at 30,000 $\times g$ to remove cell debris and large membranous organelles $(P)$. The supernatant $(S)$ was centrifuged at 100,000 $\times g$ and the membrane pellet was then resuspended and subjected to sucrose density centrifugation. The main vesicle fraction was further purified through a CPG column. The GTP-binding proteins present in the supernatant $(S)$ and pellet $(P)$ fractions after $30,000 \times g(A$, inset $)$ and $100,000 \times g(B$, inset $)$ centrifugation were monitored by their $\alpha^{32} \mathrm{P}-\mathrm{GTP}$ binding activity.

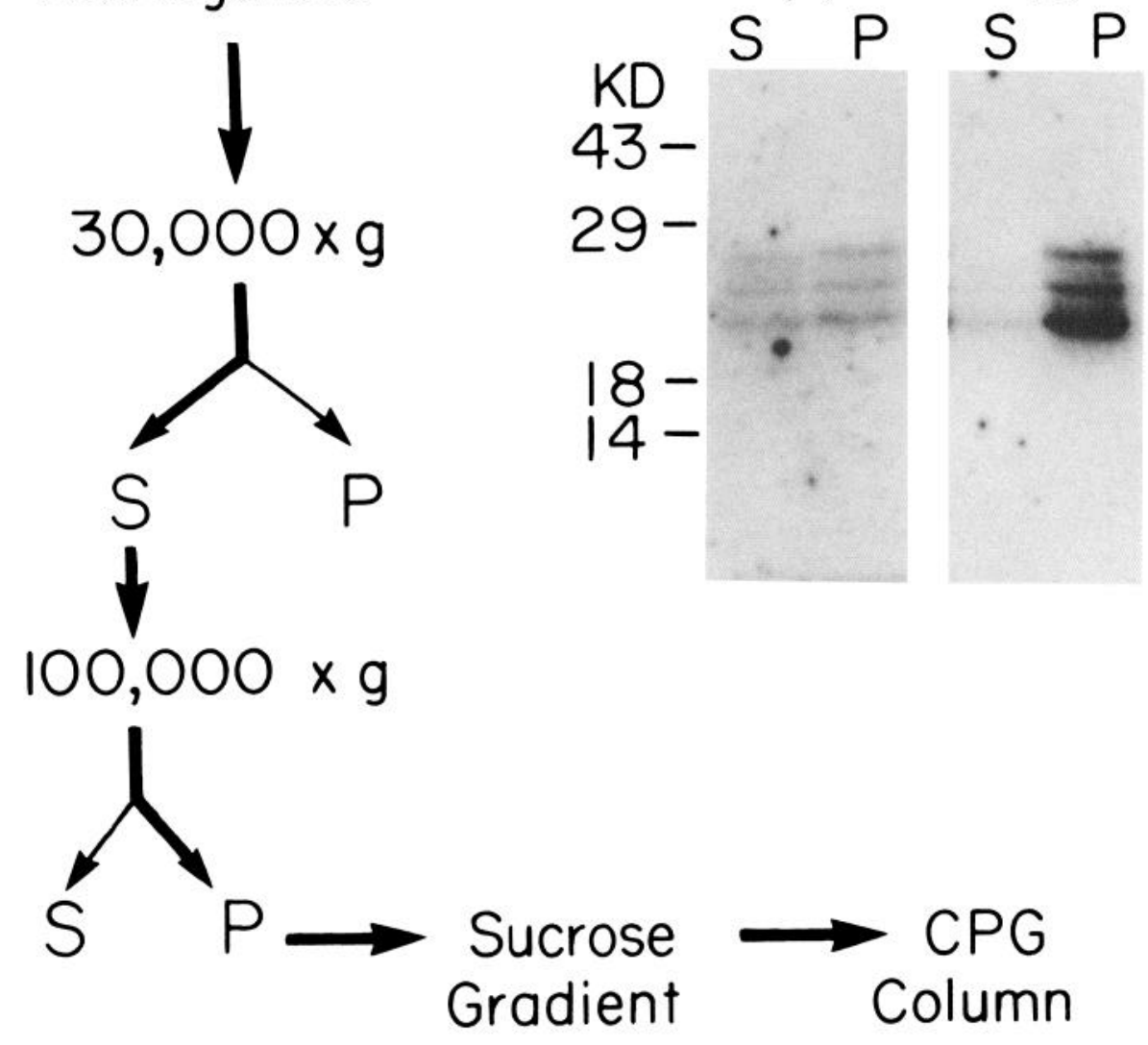

for absorbance at 260 and $310 \mathrm{~nm}$, ATP and protein content, and $\alpha^{32} \mathrm{P}-$ GTP-binding.

Electron microscopic analysis. Membranes from the CPG column chromatographed fractions were collected by centrifugation at 100,000 $\times g$ for $30 \mathrm{~min}$ and fixed in a solution of $1 \%$ glutaraldehyde, $25 \mathrm{~mm}$ sodium phosphate, $\mathrm{pH} 7.4,40 \mathrm{~mm} \mathrm{NaCl}, 1 \%$ sucrose at $4^{\circ} \mathrm{C}$ for $2-3 \mathrm{hr}$. The membrane pellet was then impregnated with $0.1 \% \mathrm{OsO}_{4}$ for $2 \mathrm{hr}$ at room temperature and embedded in Epon-Araldite.

GTP-binding assay. This was modified from procedures described previously (McGrath et al., 1984; Lapetina and Reep, 1987). An aliquot portion from each purification step was incubated with SDS sample buffer at $65^{\circ} \mathrm{C}$ for $10 \mathrm{~min}$ and fractionated on SDS-polyacrylamide gel. After electrophoretic separation, the gel was washed with 3 changes of PBS at $4^{\circ} \mathrm{C}$ for $15 \mathrm{~min}$ each. The proteins were then electroblotted to nitrocellulose filter in $50 \mathrm{~mm}$ Tris base, $384 \mathrm{~mm}$ glycine, $20 \%$ methanol at $0.3 \mathrm{~A}$ for $1 \mathrm{hr}$. The nitrocellulose filter was incubated in $10 \mathrm{~mm}$ Tris$\mathrm{HCl}, \mathrm{pH} 8.0,150 \mathrm{~mm} \mathrm{NaCl}, 5 \% \mathrm{BSA}, 0.05 \%$ Tween 20 at room temperature for $30 \mathrm{~min}$. GTP binding was performed in a solution containing $1 \mathrm{~nm} \alpha^{32}$ P-GTP in $20 \mathrm{~mm}$ Tris- $\mathrm{HCl}, \mathrm{pH} 8.0,1 \mathrm{~mm} \mathrm{MgCl}_{2}, 2$ mM DTT, $0.1 \% \mathrm{NP}-40,0.3 \% \mathrm{BSA}$, and $60 \mu \mathrm{g} / \mathrm{ml}$ yeast tRNA at room temperature for $30 \mathrm{~min}$. The filter was washed with 2 changes of 10 $\mathrm{mm}$ Tris- $\mathrm{HCl}, \mathrm{pH} 8.0,150 \mathrm{~mm} \mathrm{NaCl}, 0.5 \% \mathrm{BSA}$, and $0.5 \%$ Triton X-100 at room temperature for $15 \mathrm{~min}$ each, dried, and autoradiographed.

ADP-ribosylation with bacterial toxins. The CPG column chromatographed fractions were centrifuged at $100,000 \times \mathrm{g}$ for $30 \mathrm{~min}$ and the membranes resuspended in $10 \mathrm{~mm}$ Tris- $\mathrm{HCl} \mathrm{pH} 8.0$ at $1 / 10$ the original volume. ADP-ribosylation with pertussis toxin $(10 \mu \mathrm{g} / \mathrm{ml})$ was carried out using $40 \mu \mathrm{l}$ of membranes in $100 \mu \mathrm{l}$ of $100 \mathrm{~mm}$ Tris- $\mathrm{HCl}, \mathrm{pH} 8.0$, $10 \mathrm{~mm}$ thymidine, $10 \mathrm{~mm}$ DTT, $1 \mathrm{~mm}$ ATP, $0.1 \mathrm{~mm}$ GTP, $10 \mu \mathrm{M}$ $\mathrm{NAD}^{+}$, and $2 \mu \mathrm{Ci}$ of ${ }^{32} \mathrm{P}-\mathrm{NAD}{ }^{+}$. ADP-ribosylation with botulinum toxin C3 $(50 \mu \mathrm{g} / \mathrm{ml})$ was performed using $40 \mu \mathrm{l}$ of membranes in $100 \mu \mathrm{l}$ of $100 \mathrm{~mm}$ Tris- $\mathrm{HCl}$, pH 8.0, $10 \mathrm{~mm}$ thymidine, $10 \mathrm{~mm}$ DTT, $50 \mathrm{~mm}$ nicotinamide, $0.1 \mathrm{mM} \mathrm{GTP}, 1 \mathrm{mM} \mathrm{MgCl}, 10 \mu \mathrm{M} \mathrm{NAD}{ }^{+}$, and $2 \mu \mathrm{Ci}$ of
${ }^{32} \mathrm{P}-\mathrm{NAD}^{+}$. Both reactions were incubated at $30^{\circ} \mathrm{C}$ for $1 \mathrm{hr}$ and terminated with an equal volume of ice-cold $20 \%$ TCA. After incubation on ice for $30 \mathrm{~min}$, the proteins were collected by centrifugation and fractionated on SDS-polyacrylamide gel, stained with Coomassie Blue, dried, and autoradiographed.

\section{Results}

Two different size classes of GTP-binding proteins copurify with synaptic vesicles

Synaptic vesicles from the electric organs of the electric ray $D$. ommata were purified by differential centrifugation, flotation in a sucrose density gradient, and size fractionation on a CPG column (Carlson et al., 1978; Wagner et al., 1978). Each synaptic vesicle contains approximately 15,000 molecules of ATP, thus providing a convenient assay for their purification. The GTPbinding proteins were detected by $\alpha^{32} \mathrm{P}-\mathrm{GTP}$ binding after separation on SDS-polyacrylamide gels and transfer onto nitrocellulose filters (McGrath et al., 1984; Lapetina and Reep, 1987). Figure 1 shows that after the initial centrifugation at $30,000 \times$ $g$ to remove cell debris and intact cells, at least 3 and possibly 5 different GTP-binding proteins with MW between 20 and 29 $\mathrm{kDa}$ are evident in both the supernatant and pellet. Subsequent centrifugation of the supernatant at $100,000 \times g$ indicates that all proteins exhibiting GTP-binding activity are associated with the membrane fraction.

Next, the membrane vesicles collected by centrifugation at $100,000 \times g$ were resuspended with a tight-fitting Teflon-glass Dounce homogenizer, underlaid on a discontinuous sucrose gra- 

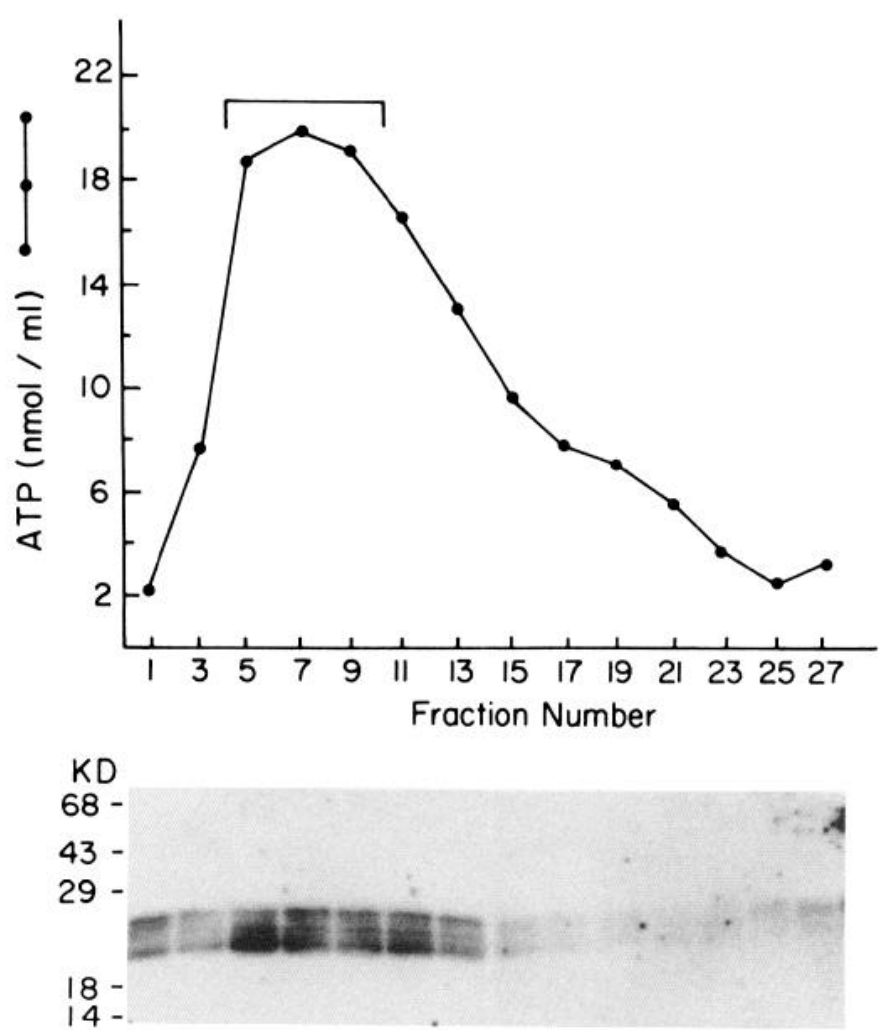

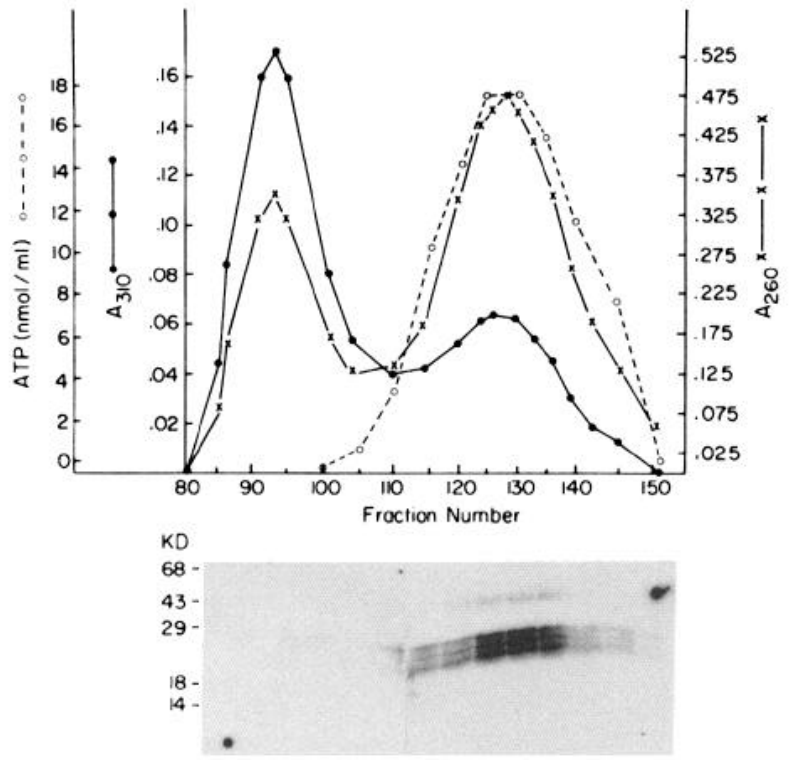

Figure 2. Left, Flotation of vesicles to their equilibrium density in sucrose gradient. The pellet after centrifugation at $100,000 \times g$ was resuspended in $0.8 \mathrm{M}$ sucrose, underlaid on a sucrose gradient, and subjected to centrifugation at $100,000 \times \mathrm{g}$ for $16 \mathrm{hr}$. Fractions ( $2 \mathrm{ml})$ were collected from the top and analyzed for ATP content (-) and GTP-binding activity (gel below). The ATP-containing fractions (bracketed) were pooled and further purified on a CPG column. Right, Size fractionation of membrane vesicles on a CPG 3000 column. The column $(2.5 \times 220 \mathrm{~cm})$ was equilibrated in 10 m $\mathrm{m}$ HEPES- $\mathrm{NaOH}, \mathrm{pH} 7.0,10 \mathrm{~mm}$ EGTA, $0.2 \mathrm{M}$ sucrose, $0.3 \mathrm{M} \mathrm{NaCl}$. The fractions $(5 \mathrm{ml})$ were analyzed for ATP content, $\mathbf{A}_{310}, \mathrm{~A}_{200}$, and $\alpha^{32}$ P-GTP binding.

dient and purified by flotation to their equilibrium densities. This removes over $95 \%$ of the contaminating soluble proteins and membrane fragments and separates the membrane vesicles according to buoyant density. Figure 2, left, shows that the GTPbinding activity correlated with the major ATP-containing fraction located near the top of the sucrose gradient. Most of the contaminating membranes remained in the bottom of the gradient as a pellet and neither contained appreciable amounts of ATP nor a significant amount of GTP-binding activity.

The next purification step takes advantage of the relatively uniformed size of synaptic vesicles. The floated membrane vesicles were chromatographed on a CPG column with a pore size which excludes large membrane vesicles. These eluted near the void volume, contained approximately $70 \%$ of the protein in the sample, and have an extremely low releasable ATP content (Fig. 2, right). The synaptic vesicles containing essentially all of the releasable ATP were eluted later from the CPG column. This was confirmed by examination of the membranous material under the electron microscope. Figure $3 A$ shows that the CPG column excluded fraction contains a collection of irregularly shaped vesicles ranging from 140 to $300 \mathrm{~nm}$ in size. Large multilamellar structures, probably representing disrupted plasma membranes or membranes from intracellular organelles such as mitochondria, are often seen in this fraction. In contrast, vesicles eluted in the later fractions are virtually free of these contaminating membrane structures (Fig. 3B). They appear as slightly electron-dense vesicles and are relatively homogeneous in size with an average diameter of $86 \pm 3 \mathrm{~nm}$ which are identical to synaptic vesicles present in the electric organ in situ.

Two different size classes of GTP-binding proteins are associated with the synaptic vesicle fraction: one or more with $\mathrm{MW}$ between 37 and $41 \mathrm{kDa}$ and at least 3-5 with MW between 20 and $29 \mathrm{kDa}$. The higher-MW GTP-binding proteins, which were not detectable in the earlier stages of the purification by the $\alpha^{32}$ P-GTP overlay technique, are clearly evident in the purified CPG fraction. The simplest explanation is that these proteins are enriched after CPG column chromatography and that their levels at the earlier stages of purification are below the detection limit of the $\alpha^{32}$ P-GTP overlay technique. The lower-MW GTPbinding proteins are clearly enriched in the synaptic vesicle fraction (Fig. 2, right). However, estimation of the relative abundance of the various GTP-binding proteins based on the intensity of the autoradiographed bands, even within the linear range of the photographic film, may not truly reflect the amount of ${ }^{32}$ P-GTP bound for this is also dependent upon the binding affinity, number of binding sites, and extent of protein renaturation. It is also not clear whether the different GTP-binding proteins are uniformly distributed among all of the vesicles or differentially associated with a subpopulation of vesicles.

\section{Synaptic vesicle-associated GTP-binding proteins are modified by bacterial toxins}

The ability of bacterial toxins to covalently modify the GTPbinding proteins has not only provided insight into the molec- 


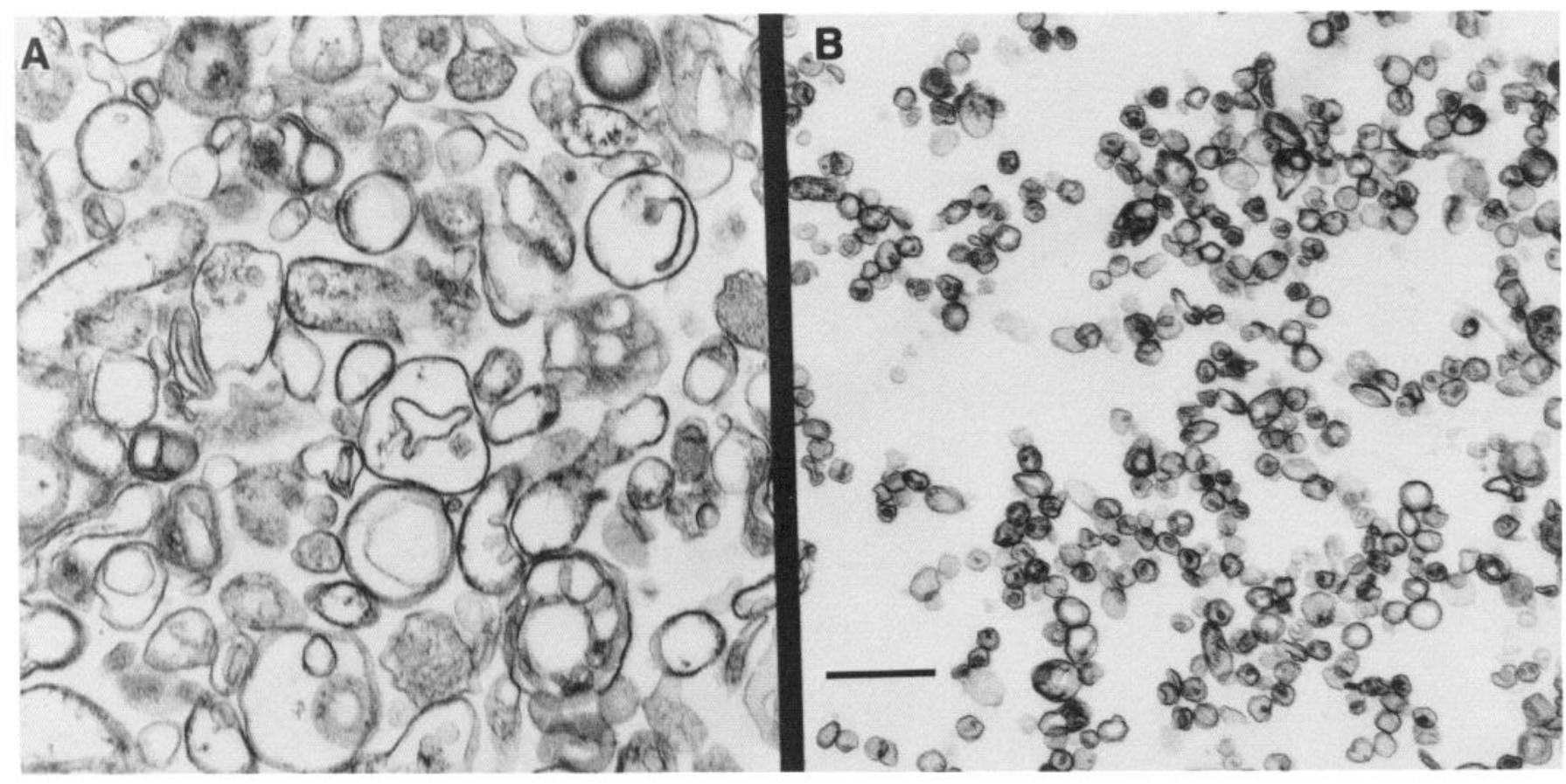

Figure 3. Electron micrograph of the membrane vesicles from the CPG column excluded fraction $(A)$ and the synaptic vesicle fraction $(B)$. The membranes were collected by centrifugation at $100,000 \times \mathrm{g}$, and fixed in phosphate-buffered isotonic solution of sucrose and glutaraldehyde prior to embedding and sectioning. Scale bar, $400 \mathrm{~nm}$.

ular mechanism of toxin action but also served as a valuable tool in their biochemical characterization. To determine the nature of the GTP-binding proteins associated with the synaptic vesicles, the membranes were treated with pertussis and botulinum toxins in the presence of ${ }^{32} \mathrm{P}-\mathrm{NAD}^{+}$. Pertussis toxin catalyzed the ADP-ribosylation of the higher-MW GTP-binding proteins (Fig. 4) which upon resolution in a lower cross-linked polyacrylamide gel clearly reveals 2 distinct species (data not shown). Although a smaller amount of contaminating pertussis toxin-sensitive protein was detected in the excluded fraction (estimated at $12 \%$ of the total by densitometric scanning), most of the ADP-ribosylated proteins fractionated with the synaptic vesicles. Thus, these synaptic vesicle-associated GTP-binding proteins are considered to be more closely related to $G_{i}$ and $G_{o}$. Botulinum toxin, on the other hand, catalyzes the ADP-ribosylation of some of the lower-MW GTP-binding proteins (Fig. 4). As in the pertussis toxin-sensitive proteins, the botulinum toxin-catalyzed ADP-ribosylated proteins are predominantly associated with the synaptic vesicles. Assuming ADP-ribosylation occurred at equal efficiency, this represents a 20 -fold enrichment of the botulinum toxin-sensitive GTP-binding proteins in the vesicle fraction relative to the excluded fraction. It is interesting to note that only 2 of the 5 or more lower-MW GTP-binding proteins detectable using the $\alpha^{32} \mathrm{P}-\mathrm{GTP}$ overlay technique are covalently modified by botulinum toxin. This may reflect a difference in detection limits between the 2 techniques or insensitivity of some GTP-binding proteins to the toxin. However, the absence of additional ADP-ribosylated protein in a reaction using 20 -fold more vesicle proteins supported the latter possibility (data not shown).

\section{Discussion}

The electric organ of the electric ray, D. ommata, is a highly innervated structure and provides an enriched source of cho- linergic synaptic vesicles. These were purified by differential centrifugation, flotation in a sucrose density gradient and size fractionation on a CPG column (Carlson et al., 1978; Wagner et al., 1978). The GTP-binding proteins were monitored throughout the purification procedure by $\alpha^{32}$ P-GTP binding after separation on SDS-polyacrylamide gels and transfer onto nitrocellulose filters (McGrath et al., 1984; Lapetina and Reep, 1987). Two different size classes of GTP-binding proteins are clearly associated with the synaptic vesicle fraction: one or more with MW between 37 and $41 \mathrm{kDa}$ and at least 3-5 with MW between 20 and $29 \mathrm{kDa}$. The lower-MW GTP-binding proteins are tightly associated with the membrane fraction in the early stages of the purification. After removal of other contaminating intracellular membranes and cytosol by a flotation sucrose density gradient, these lower-MW GTP-binding proteins remain associated with the major ATP-containing vesicle fraction. Subsequent size fractionation of the floated membrane vesicles on a CPG column revealed that these proteins copurify with vesicles with an average diameter of $86 \pm 3 \mathrm{~nm}$, identical in size and morphology to synaptic vesicles in the electric organ in situ. A second set of GTP-binding proteins with MW between 37 and $41 \mathrm{kDa}$, which were not detectable with the $\alpha^{32} \mathrm{P}-\mathrm{GTP}$ overlay technique in the earlier stages of the purification, was also found to copurify with the synaptic vesicle fraction. Thus, it can be concluded that both size classes of GTP-binding proteins form an integral part of synaptic vesicles.

$\mathrm{G}$ proteins have been shown to be covalently modified by bacterial toxins. For example, $G_{s \alpha}$ is ADP-ribosylated in the presence of a cytosolic ADP-ribosylation factor or ARF by cholera toxin (Kahn and Gilman, 1984); pertussis toxin catalyzes the ADP-ribosylation of the $\alpha$ subunit of $\mathrm{G}_{\mathrm{i}}, \mathrm{G}_{\mathrm{o}}$, and $\mathrm{G}_{\mathrm{t}}$ (Stryer, 1986; Gilman, 1987); botulinum toxin ADP-ribosylates several low-MW GTP-binding proteins in bovine brain (Kikuchi et al., 1988a, b), bovine adrenal gland (Morii et al., 1988), and human 


\section{pertussis}

\section{botulinum}

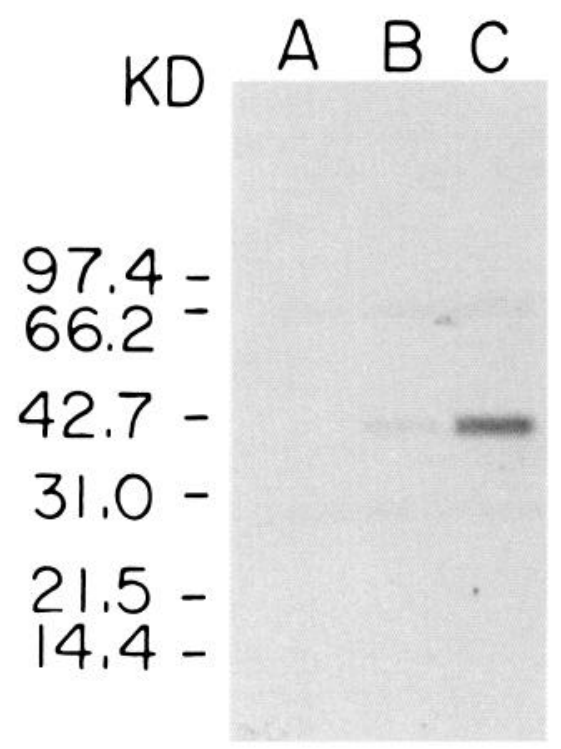

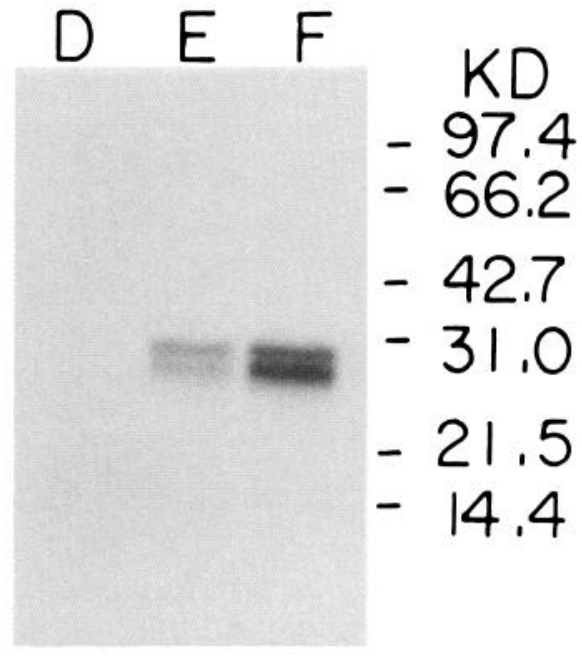

Figure 4. Covalent modification of the GTP-binding proteins with pertussis and botulinum toxins. Membranes from the CPG column chromatographed fractions were collected by centrifugation and resuspended in $10 \mathrm{~mm}$ Tris$\mathrm{HCl}, \mathrm{pH} 8.0$, at $1 / 10$ the original volume. ADP-ribosylation with pertussis and botulinum $\mathrm{C} 3$ toxins was carried out in the presence of $2 \mu \mathrm{Ci}$ of ${ }^{32} \mathrm{P}$ $\mathrm{NAD}^{+}$. The proteins were precipitated with $10 \%$ TCA, fractionated on SDSpolyacrylamide gel, and autoradiographed. ADP-ribosylation with the toxin alone $(A, D)$; with membranes from the excluded fraction $(B, E)$; with membranes from the synaptic vesicle fraction $(C, F)$. neutrophils (Bokoch et al., 1988). Based on their sensitivity to ADP-ribosylation by pertussis toxin, the higher-MW synaptic vesicle associated GTP-binding proteins are considered to be more closely related to $G_{i}$ and $G_{0}$. Of the 5 or more lower-MW GTP-binding proteins detectable using the $\alpha^{32} \mathrm{P}$-GTP overlay technique, only 2 are sensitive to ribosylation by botulinum toxin. In contrast to botulinum toxin-catalyzed ADP-ribosylation in other systems (Bokoch et al., 1988; Kikuchi et al., 1988 a,b; Morii et al., 1988), only the larger 2 (MW between 27 and $29 \mathrm{kDa})$ of the lower-MW GTP-binding proteins are modified by the toxin.

In summary, we have shown that purified synaptic vesicles from the electric organ of the electric ray, D. ommata, contain a number of GTP-binding proteins. By analogy to other systems, the higher-MW GTP-binding proteins may play a role in signal transduction. However, it is not apparent what receptor or effector systems are coupled to these proteins in the synapse. One may speculate that they are transducing signals from factors which are crucial for the maintenance of a functional synapse. On the other hand, it is equally tempting to speculate that they may directly regulate voltage-sensitive ion channels, such as $\mathrm{Ca}^{2+}$ channels, thus modulating neurotransmitter release. Although localized to synaptic vesicles, it would not be surprising to find these GTP-binding proteins associated, at least transiently, with the presynaptic membrane during vesicular fusion. The GTP-binding proteins, as well as other synaptic vesicle proteins, may recycle along with components of the plasma membrane during the regeneration of endocytotic vesicles. Thus, the GTP-binding proteins may not only be involved in directing the transport of synaptic vesicles to the active zone but also in regulating synaptic vesicle fusion and subsequent membrane recycling. The presence of multiple forms of GTP-binding proteins is particularly suitable for the multifaceted aspects of membrane trafficking in the synaptic terminal. The GTP-binding proteins reported here may also play a role in the dynamic remodeling of synaptic membrane which occurs during devel- opment and in long-term memory processes (Bailey et al., 1981; Bailey and Chen, 1983; Kretz et al., 1986). It becomes an important task to determine whether disruption of any of these cellular processes can be correlated with the action of synaptic vesicle GTP-binding proteins.

\section{References}

Audigier, Y., S. K. Nigam, and G. Blobel (1988) Identification of a $\mathrm{G}$ protein in rough endoplasmic reticulum of canine pancreas. J. Biol. Chem. 263: 16352-16357.

Bailey, C. H., and M. Chen (1983) Morphological basis of long-term habituation and sensitization in Aplysia. Science 220: 91-93.

Bailey, C. H., R. D. Hawkins, M. Chen, and E. R. Kandel (1981) Interneurons involved in mediation and modulation of gill-withdrawal reflex in Aplysia. IV. Morphological basis of presynaptic facilitation. J. Neurophysiol. 45: 340-360.

Banga, H. S., S. K. Gupta, and M. B. Feinstein (1988) Botulinum toxin D ADP-ribosylates a 22-24 KDa membrane protein in platelets and HL-60 cells that is distinct from p21 ${ }^{\text {N-RAS }}$. Biochem. Biophys. Res. Commun. 155: 263-269.

Barbacid, M. (1987) ras genes. Annu. Rev. Biochem. 56: 779-827.

Bhullar, R. P., and R. J. Haslam (1988) $\mathrm{G}_{\mathrm{n}}$-proteins are distinct from ras $\mathrm{p} 21$ and other known low molecular mass GTP-binding proteins in the platelets. FEBS Lett. 237: 168-172.

Bokoch, G. M., C. A. Parkos, and S. M. Mumby (1988) Purification and characterization of the 22,000-Dalton GTP-binding protein substrate for ADP-ribosylation by botulinum toxin, $G_{22 K}$. J. Biol. Chem. 263: 16744-16749.

Bourne, H. R. (1988) Do GTPases direct membrane traffic in secretion? Cell 53: 669-671.

Brocklehurst, K. W., and H. B. Pollard (1988) Pertussis toxin stimulates delayed-onset, $\mathrm{Ca}^{+}$-dependent catecholamine release and the ADP-ribosylation of a $40 \mathrm{kDa}$ protein in bovine adrenal chromaffin cells. FEBS Lett. 234: 439-445.

Burgoyne, R. D., and A. Morgan (1989) Low molecular mass GTPbinding proteins of adrenal chromaffin cells are present on the secretory granule. FEBS Lett. $245: 122-126$.

Carlson, S. S., J. A. Wagner, and R. B. Kelly (1978) Purification of synaptic vesicles from elasmobranch electric organ and the use of biophysical criteria to demonstrate purity. Biochemistry 17: 11881199. 
Chardin, P., and A. Tavitian (1986) The ral gene: a ras related gene isolated by the use of synthetic probe. EMBO J. 5: 2203-2208.

Doucet, J. P., S. Fournier, M. Parulekar, and J. M Trifaro (1989) Detection of low molecular mass GTP-binding proteins in chromaffin granules and other subcellular fractions of chromaffin cells. FEBS Lett. 247: $127-131$.

Dunant, Y., F. Loctin, J. Marsal, D. Muller, A. Parducz, and X. Rabasseda (1988) Energy metabolism and quantal acetylcholine release: Effects of botulinum toxin, 1-fluoro-2,4-dinitrobenzene, and diamide in the Torpedo electric organ. J. Neurochem. 50: 431-439.

Gilman, A. G. (1987) G proteins: Transducers of receptor-generated signals. Annu. Rev. Biochem. 56: 615-649.

Goud, B., A. Salminen, N. C. Walworth, and P. J. Novick (1988) A GTP-binding protein required for secretion rapidly associates with secretory vesicles and plasma membrane in yeast. Cell 53: 753-768.

Habermann, E., and F. Dreyer (1986) Clostridial neurotoxins: Handling and action at the cellular and molecular level. Curr. Top. Microbiol. Immunol. 129: 93-179.

Kahn, R. A., and A. G. Gilman (1984) Purification of a protein cofactor required for ADP-ribosylation of the stimulatory regulatory component of the adenylate cyclase by cholera toxin. J. Biol. Chem. 259: 6228-6234.

Kawata, M., Y. Matsui, J. Kondo, T. Hishida, T. Teranishi, and Y. Takai (1988) A novel small molecular weight GTP-binding protein with the same putative effector domain as the ras proteins in bovinc brain membranes. Purification, determination of primary structure and characterization. J. Biol. Chem. 263: 18965-18971.

Kikuchi, A., K. Yamamoto, T. Fujita, and Y. Takai (1988a) ADPribosylation of the bovine brain rho protein by botulinum toxin type C1. J. Biol. Chem. 263: 16303-16308.

Kikuchi, A., T. Yamashita, M. Kawata, K. Yamamoto, K. Ikeda, T. Tanimoto, and Y. Takai (1988b) Purification and characterization of a novel GTP-binding protein with a molecular weight of 24,000 from bovine brain membranes. J. Biol. Chem. 263: 2897-2904.

Kretz, R., E. Shapiro, C. H. Bailey, and E. R. Kandel (1986) Presynaptic inhibition by an identified presynaptic inhibitory neuron. II. Presynaptic conductance changes caused by histamine. J. Neurophysiol. 55: 131-146.

Lapetina, E. G., and B. R. Reep (1987) Specific binding of [ $\alpha{ }^{-3}$ 'P]GTP to cytosolic and membrane-bound proteins of human platelets correlates with the activation of phospholipase C. Proc. Natl. Acad. Sci USA 84: 2261-2265.

Madaule, P., and R. Axel (1985) A novel ras-related gene family. Cell 41: $31-40$.

Matsui, Y., A. Kikuchi, J. Kundo, T. Hishida, Y. Teranishi, and Y. Takai (1988) Nucleotide and deduced amino acid sequences of a GTP-binding protein family with molecular weights of 25,000 from bovine brain. J. Biol. Chem. 263: 11071-11074.

Matsuoka, I., H. Sakuma, B. Syuto, K. Moriishi, S. Kubo, and K. Kurihara (1989) ADP-ribosylation of 24-26-kDa GTP-binding proteins localized in neuronal and non-neuronal cells by botulinum neurotoxin D. J. Biol. Chem. 264: 706-712.

McGrath, J. P., D. J. Capon, D. V. Goeddel, and A. D. Levinson (1984) Comparative biochemical properties of normal and activated human ras p21 protein. Nature 310: 644-649.
Melancon, P., T. Serafini, M. L. Gleason, L. Orci, and J. E. Rothman (1987) Involvement of GTP-binding " $G$ " proteins in transport through the Golgi stack. Cell 51: 1053-1062.

Milligan, G. (1988) Techniques used in the identification and analysis of function of pertussis toxin-sensitive guanine nucleotide binding proteins. Biochem. J. 255: 1-13.

Morii, N., A. Sekine, Y. Ohashi, K. Nakao, H. Imura, M. Fujiwara, and S. Narumiya (1988) Purification and properties of the cytosolic substrate for botulinum ADP-ribosyltransferase: Identification as an $\mathbf{M}_{\mathrm{r}}$ 22,000 guanine nucleotide-binding protein. J. Biol. Chem. 263. 12420-12426.

Narumiya, S., A. Sekine, and M. Fujiwara (1988) Substrate for botulinum ADP-ribosyltransferase, $\mathrm{Gb}$, has an amino acid sequence homologous to a putative rho gene product. J. Biol. Chem. 263: 1725517257.

Ohasi, Y., and S. Narumiya (1987) ADP-ribosylation of a $\mathbf{M}_{\mathbf{r}} 21,000$ membrane protein by type D botulinum toxin. J. Biol. Chem. 262: 1430-1433.

Poulain, B., L. Tauc, E. A. Maisey, J. D. F. Wadsworth, P. M. Mohan, and J. O. Dolly (1988) Neurotransmitter release is blocked intracellularly by botulinum neurotoxin, and this requires uptake of both toxin polypeptides by a process mediated by the larger chain. Proc. Natl. Acad. Sci. USA 85: 4090-4094.

Salminen, A., and P. J. Novick (1987) A ras-like protein is required for a post-Golgi event in yeast secretion. Cell 49: 527-538.

Schmitt, H. D., P. Wagner, E. Pfaff, and D. Gallwitz (1986) The rasrelated YPTI gene product in yeast: A GTP-binding protein that might be involved in microtubule organization. Cell 47: 401-412.

Segev, N., J. Mulholland, and D. Botstein (1988) The yeast GTPbinding YPTI protein and a mammalian counterpart are associated with the secretion machinery. Cell 52: 915-924.

Simpson, L. L. (1986) Molecular pharmacology of botulinum and tetanus toxin. Annu. Rev. Pharmacol. Toxicol. 26: 427-454.

Stryer, L. (1986) G proteins: A family of signal transducers. Annu. Rev. Cell Biol. 2: 391-419.

Tanaka, T., H. Yokohama, M. Negishi, H. Hayashi, S. Ito, and O. Hayaishi (1987) Pertussis toxin facilitates secretogogue-induced catecholamine release from cultured bovine adrenal chromaffin cells. Biochem. Biophys. Res. Commun. 144: 907-914.

Touchet, N., P. Chardin, and A. Tavitian (1987) Four additional members of the ras gene superfamily isolated by an oligonucleotide strategy: Molecular cloning of YPT-related cDNAs from a rat brain library. Proc. Natl. Acad. Sci. USA 84: 8210-8214.

Toutant, M., D. Aunis, J. Bockaert, V. Homburger, and B. Rouot (1987) Presence of three pertussis toxin substrates and $\mathrm{G}_{0} \alpha$ immunoreactivity in both plasma and granule membranes of chromaffin cells. FEBS Lett. 215: 339-344.

Tsai, M.-H., C.-L. Yu, F.-S. Wei, and D. W. Stacey (1989) The effect of GTPase activating protein upon ras is inhibited by mitogenically responsive lipids. Science 243: 522-526.

Wagner, J. A., S. S. Carlson, and R. B. Kelly (1978) Chemical and physical characterization of cholinergic synaptic vesicles. Biochemistry 17: 1199-1206. 